Copyright (C) 2005

SBPJor / Associação Brasileira de Pesquisadores em Jornalismo
THE OPPOSITION

BETWEEN

MEDIACENTRIC

AND SOCIOCENTRIC

PARADIGMS

LUIZ GONZAGA MOTTA

Universidade de Brasília, Brazil

ABSTRACT

This paper identifies and discusses two trends of journalism research in Brazil. In short, the hegemonic trend - the so-called 'mediacentric' trend - seeks to look at the impact journalism has on society by disseminating an authoritarian and biased world view. The counter-hegemonic trend - the so-called 'sociocentric' trend - takes into account the power of journalism, but considers it susceptible to pressures and seeks to look at the trade-offs made by organized groups in civil society and journalistic institutions. This paper argues for the second trend and considers it as an analytical stance that is less naive and more realistic. That accounts for the complexity of political game and the correlation of forces in society.

KEY-WORDS Journalism research, hegemonic paradigm, counter-hegemonic paradigm, civil society

\title{
1 - INTRODUCTION
}

It is not my intention to provide an overview of journalism research in Brazil. It is impossible to establish a clear classification of a vast amount of research conducted by 270 communications schools, 20 master's programs, 11 doctoral programs, and 72 research groups operating under the National Council for Scientific and Technological Development - CNPq. In addition, the variety of topics, approaches, subjects, and methods of research makes it difficult to draw clear boundaries in the field. This research work is continually presented by researchers in hundreds of academic conferences and meetings at national, regional and local level. Grouping the countless conceptual and methodological trends in journalism research in a consistent fashion would require gargantuan efforts and such a huge endeavor would render barely intelligible results' . 
Some attempts at reviewing the research work on journalism in Brazil have recently been made. On research on communication studies in general and on journalism in particular, C. Berger (2002) argues that the field has been legitimized since the 1970s, acknowledged as an interdisciplinary domain and has competing professional and technical approaches. Yet to have a scientific status, its object of inquiry is in the making and it is in the process of establishing itself as a field of knowledge. In Berger's view, journalism research is an illustration of the interdisciplinary background, where there is a combination of the history of Brazil and the history of press, theories of discourse and journalistic discourse, the feminine gender and stereotypes, and so forth. M. Pereira and J. Wainberg (2000) note that Brazilian research is still at a nascent stage when compared with that of other countries, and that studies have little impact on the professional practice. Marques de Melo (1999) identifies in the diversity of areas of research a potential for acknowledgment by professional bodies $^{2}$.

In this paper, rather than making a summary, I chose to follow another path. I intend to make a brief recapitulation of what I think has been the hegemonic paradigm of journalism research in Brazil over the past few decades and then to describe a counter-hegemonic trend. Therefore, my approach will focus on the conflict that exists within journalism research. I risk oversimplifying the issue, reducing the wealth of research and overlooking a great deal of qualified work. The path I have chosen to take seems to me, however, more fruitful. This is so not only because it identifies an innovative attitude, to which I will give special attention, but because it establishes a link between journalism research and social history in Brazil and consolidation of democracy in this country. Hence, it makes my analysis more comprehensible in sociological terms. Also, it facilitates the discussion from an analytical point of view.

\section{2 - PARADIGMS IN CONFRONTATION}

The hegemonic paradigm of journalism research in Brazil will be described as 'mediacentric'. The studies that conform to this paradigm focus on the media to look at the impact journalism has on society by disseminating an authoritarian 'world view' based on the professional and institutional culture, and on market requirements. A number of approaches has developed and burgeoned, ranging from very different to even opposing approaches, such as Marxism, Functionalism, and Structuralism. With due consideration of the differences, everyone grants 
a certain degree of autonomy to journalism as an active social actor in the democratic game and seeks to acknowledge its power of shaping society's political culture, which reaffirms its hegemonic right to have a voice and to be allowed to use this voice.

The counter-hegemonic paradigm will be described as 'sociocentric'. It relies on different assumptions. It takes into consideration the power of journalism and the privileged space it occupies in terms of contemporary sociability. It admits that the social and political contexts undergo changes when the media and new approaches, resources and languages of journalism come into play. It accounts for mediatization and adjustment of the social factor to this new environment (a process underway). However, it considers journalism susceptible to social contradictions and pressures exerted by the civil society, and it is subject to countless compromises. According to it, journalism may give in to the interests of the various social actors depending on the correlation of forces. Research works seek to investigate to what extent organized social groups can put their world views forward and revert authoritarian stances adopted by the media, thus magnifying their voices. This trend is not exclusive to journalism nor is it recent, but it started to gain momentum within academic communities in Brazil after the previous paradigm.

Since I have chosen to focus on the conflict between these two paradigms, I will disregard other major contradictions of journalism research in Brazil. For example, a conflict to which researchers have paid much attention over the past few years has undoubtedly been the discussion between epistemologies of objectivity and subjectivity in journalistic approaches and discourses. This conflict reflected the debate between Realism and Constructivism in social sciences (this debate is still on-going). Both within the educational and professional arenas this discussion rages on. A great deal of papers and books published over the past few decades have this conflict as their fundamental issue.

S. Moretzsohn (2002) strongly argues that the subjectivity in the process of capturing facts shows that journalism "is not the discourse of reality - as it is claimed to be -, but rather a discourse on reality". According to S. Moretzsohn, a technical discourse is successful and more powerful today, but this does not mean that it is final. She identifies a need to move from the paradigm of bias - which unveils objectivity towards the paradigm of ideology, i.e., a return to a vision of an activist profession, in relation to which new editorial criteria are required. This remains unanswered.

E. Meditsch (2001) argues against both Positivism and the paradigm 
of ideology. In his view, the complaints under the paradigm of ideology have played a demolishing role regarding the myths of objectivity, but the omission of dialectics from which it was born has led this paradigm to sterile reductionism. Everything has become subjective: "every and all truth started to reflect a political intention to be demolished by competing intentions under fierce ideological cross-fire in the struggle for a prevailing definition of political correctness". In conclusion, Meditsch affirms that this development does not make it possible to overcome the reductionism that is criticized at its source; it simply replaces it by others. He proposes that the issue be placed under the theory of argumentation (journalistic pragmatics) and under intersubjectivity, where the distinction between objectivity and subjectivity is blurred and becomes a continuum. I fully agree with this proposition.

I see this discussion must be furthered, but I cannot dwell on this thought-provoking epistemological topic here. I have recently made considerations on the contradiction between objectivity and subjectivity in journalism as a profession and as a discipline based on influences of the broader debate within social sciences (Motta, 2003a). My conclusion was that the profession underwent a 'mediamorphosis' as new technologies and languages were introduced, while for journalism as a discipline a new constructivist paradigm was developed based on inputs from philosophy of language, modern rhetoric, symbolic anthropology, and cognitive sciences. This new paradigm of journalism as a discipline has not managed, however, to work its way into the profession, where the axiom of objectivity remains in a hegemonic position ${ }^{3}$.

I have also made considerations on the same contradiction in light of journalistic pragmatics (Motta, 2003b). I argued that the contradiction between objectivity and subjectivity (logos and mythos) is necessarily a part of journalistic communication. In line with E. Meditsch's thoughts, I argued that a journalist seeks to ensure buy-in from his/her interlocutor through a 'contract' that emphasizes the referent, but the 'negotiation' of meanings in journalistic communication varies according to journalistic rhetoric and the fancy of readers. In pragmatic analyses of journalistic communication, I have advocated the need to take into consideration the variation in journalistic rhetoric on the continuum between objectivity and subjectivity. I argued for the need for research to take into account that news is intended to be an objective account of reality because this is the tenet of the journalistic language. But I also identified the need to take into account at the same time the symbolic meanings that take place through implicatures. In other words, "the focus of analysis must be on 
the contradiction between an intended objectivity and the presence of aesthetic and subjective elements (in journalistic language) that reveal

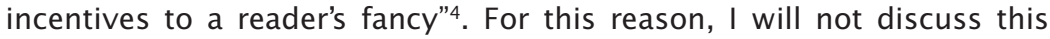
conflict now. Although the discussion is not exhausted, I would like to refer readers to my abovementioned articles.

I quickly stressed this discussion because of its central importance for Brazilian research, but I left out other topics that I cannot approach here. I will now go back to the discussion about the conflict between the mediacentric and sociocentric paradigms as the backbone of my point. Before, however, I would like to make a warning: I am not placing journalism on one side and civil society on the other side as if they were politically opposing forces or a social contraction in itself. In fact, commercial journalism belongs to the historical hegemonic bloc. The division I am doing here derives from an analytical and argumentative need, and it is intended to provide a clearer context for journalism research within the changes taking place in society. This is an ex post ploy to discuss two axes of research that seem to employ different approaches, even though these contradictory paradigms can bear a certain similarity with the existing social contradictions ${ }^{5}$.

\section{THE MEDIACENTRIC (HEGEMONIC) PARADIGM ${ }^{6}$}

The mediacentric paradigm is hegemonic because it has been the prevailing research approach since the 1960s. Its assumption is that media in general - and journalism in particular - have a demolishing effect on society. The fact that the contents of journalism of the masses are inexorably at the mercy of commercial and business determinations has a politically conservative character that is impermeable to popular or opposing social interests. It argues that journalism manipulates information according to its commercial and ideological rationale, that is contents are mediocre, sensationalistic (the spectacle rationale), homogenizes society's mindset and cause social depoliticization. It allocates a certain power to journalism vis-à-vis society and rarely takes into consideration society's actions on journalism. Therefore, an economic and political determinism prevails over social determinism.

This widespread critical attitude by researchers has a historical reason. Research in communication studies appears in Brazil during the 1960s and becomes well established in the 1970s as the first postgraduate programs are created. At that time, the country was under a single-minded, all-powerful and authoritarian political regime, 
which thwarted liberal-developmental expectations from the previous decade. Excessive concentration of power in the hands of a military administration curtailed political debate and did away with divergences by means of force. Social movements were vigorously curbed and political beliefs were enfeebled. The ability to act and react was reduced. During the same period, media concentration started and use of new centralizing technologies became widespread. The establishment of networks made communication possible at large scale. Brazil underwent a quick industrialization and urbanization process and mass society was established, though it was an exclusive society. Regional cultures were weakened by internationalized consumerism. Political resistance was restricted to a few niches - such as universities - and journalism researchers rally around other intellectual groups to denounce political and communications authoritarianism. Research was contaminated by political debate to denounce authoritarianism and media prepotency ${ }^{7}$.

I cannot provide here a comprehensive review of the contents of this paradigm, nor can I enumerate the diversity of its topics and methodologies, and this is so because they do not constitute a fully consistent ensemble. Within the mediacentric paradigm, there are research works that only conform to it in part, and there are distinct and even opposing approaches, objects and methodologies. Aware that I risk being unjust by focusing on only one representative who cannot even be taken as a typical instance of this paradigm, in order to illustrate the mediacentric principle I would like to mention an author whose work has significantly influenced journalism as a discipline in Brazil. I am talking about C. Marcondes Filho, whose most influential work I will discuss: newly published book Comunicação \& Jornalismo - A saga dos cães perdidos (Communication \& Journalism - Saga of the lost dogs). I make special mention of this author because I consider him as paradigmatic of the axis of research that keeps repeating the assertion that journalism has the power to manipulate society at its whim ${ }^{8}$.

In his book, after a summary of journalism from its pre-history to the present day, this author affirms that journalism has lost its modern spirit, its raison d'être (the 'truth', transparency). In his view, journalism began to lose ground to the irrational and magic media seduction - TV - and to the hegemony of techniques in the late 20th century. He describes journalism in the late 20th century as the fourth and last journalism, a terminal process that in his opinion started around the 1970s. He labels the latter as 'awareness industry', an inflation of press releases that start to be provided to newspapers by private and public agents - press officers 
- that mingle with and are mistaken for journalistic information.

Before that time, says Marcondes Filho, advertising and public relations had started to struggle for space in the press as an indispensable factor for monopolistic capitalism to survive (after 1930). "It shifts from a 'mass' communication industry - journalism - to actual awareness industry", he says. (Marcondes Filho, 32) With new technologies, the stunning increase in production changes journalism in the sense of generating profit and becoming a self-sustainable business. As a result, journalism stopped being a free, uncommitted open channel for all and each manifestation of social actors and became a market-oriented product. Journalistic boldness and creativity lose ground to inaction and market-oriented repetitiousness. Daily and continual computerized production in a newspaper tends to crush facts - including analyses - transforming them into an "odorless, colorless, and tasteless" product despite their attractive look. (Marcondes Filho, 37)

With the advent of television, editing and visual fantasies come to the foreground in journalism thanks to electronic image editing, special effects and mixing: "the visual spectacle becomes as important as the very event shown on TV. An investment is made in colors, set design, motions, curiosities, and visual pyrotechnics, which all make TV 'an oneiric device' in the first place, a bridge to the world of dreams" (Marcondes Filho, 42). Hence, journalism becomes a conservative factory of dreams that "rebuilds the world on a daily basis by imposing its crystallized truth on people, on facts, on new developments, and it performs a soothing and rewarding role of keeping the world just as it is" (Marcondes Filho, 110). In conclusion, television journalism rebuilds convincingly the world without any clashes.

I do not think a discussion of the author's views is necessary here. The above quotations are clear enough as a reflection of the mediacentric paradigm. I would like only to revisit some of his statements on the impermeability journalism has to social contradictions in order to finish this very brief review of mediacentric principles. According to Marcondes Filho's analysis, there do not seem to be social contradictions in this country. If they do exist, media and journalism remain immune to them. With an apocalyptic language, he affirms that a disenchantment process at global level and a crisis of ideologies that result in the post-history era are taking place: "Since there are no more causes to fight for ... there are no more clear distinctions between cultures and countries, the global civilization has become a wholeness without tomorrow" (Marcondes Filho, 26-7). 
According to this author, what used to characterize commitment, the power of struggle, and combativeness of modern men was a historical determination of conquests - political, economic, aesthetic conquests - that channeled energies and feelings of sympathy. Now, post-history eradicates games, the "impossibility of fighting against", a "desire for nothing". (Marcondes Filho, 27) What is more, he says, the world of dreams - of TV - has no contradictions; its situations of fear and anguish are transitory and harmless (Marcondes Filho, 42). The journalistic profession becomes minimalistic, the economy is no longer addressed in its relationships with social actors; political coverage only highlights ephemeral and curious events. Gone are revolutionary actors (individuals, classes), trade unions, political parties, intellectual oppositionists, and civil society organizations that comprised the public community who marched on the streets, who complained, who gathered around ideas, ideologies, and world views (Marcondes Filho, 44). In this world free from contradictions, according to him, journalism merely replicates homogeneous positions as a "spokesperson of the elites, of the rhetoric of establishment". This is the cause of decay and disappearance of journalism, "the end of the saga of the untamable dogs" (Marcondes Filho, 58).

I cannot afford to omit my differences with the author here regarding the assertions above. For sure, this is not the country or the world where I live. In the country where I live, differences have never been so clear. The country where I live is replete with contradictions; oppositions; political confrontations; parties, trade unions and social movements that act, fight, achieve, lose their track, and experience victories and defeats. Sometimes they act reasonably; sometimes they act contradictorily. Public demonstrations of different sorts and intensities sometimes undergo a setback, but they bounce back strongly later, setting up camping tents even in the Esplanade of the Ministries in Brasilia - quite close to central power. The country where I live is replete with social groups and movements that come together, protest, march on the streets, make demands, forge ahead, lose track along the way, make it up, and get back on track. In the country where I live there is much disenchantment, but utopias live on. There are many causes to fight for; people dearly dream of and desire a different future.

In the country where I live, to some extent - sometimes to a greater extent, sometimes to a lesser extent -, journalism reflects these contradictions. It is a predominantly conservative country - and things could not be different in an exclusive country such as ours -, but it does 
echo social struggles. It is not, and could not be, impermeable to several political conflicts, and it is full of tensions. It tends to be a superficial country, but its practices and languages are not monolithic; they seem more of a permanent battle field. The contents of Brazilian journalism are full of tensions, they echo social struggles and contradictions, they open and close spaces according to the circumstances. As a social actor, it builds alliances, negotiates power, makes concessions to social movements, has political advances and retreats all the time. In my opinion, research does not have the right to ignore this.

Afonso Albuquerque (1998) has described the epistemological approach that I call mediacentric as 'paradigm of editorial manipulation of the news'. Using a discourse analysis methodology of a more essayistic nature, he said, these studies repeatedly denounced journalistic coverage of conservative causes and parties being favored to the detriment of popular causes. Although his arguments are different from the ones being discussed herein, he observed that the application of this paradigm to an analysis of Brazilian journalism was not totally purposeless in view of the extent to which extra-journalistic factors interfere with coverage, such as political and economic interests. He came to the conclusion, however, that this model was limited because: 1) it narrows justification of political coverage down to extra-journalistic factors without taking into consideration the active role played by journalists; 2 ) it makes it difficult to understand the historical process against a cultural backdrop; 3) the emphasis placed on manipulation constrains analysis of factors interfering with the news making process, especially alternative communication strategies and influences from other sectors.

Criticism of this paradigm is not recent. I myself criticized pessimistic theoretical models over twenty years ago (Motta, 1983). I argued that even critical studies were restricted to formally denouncing ideological imposition and cultural manipulation as if individuals and social groups were entirely passive. I criticized research works that merely went through the motions to repeat accusations of ideological imposition and cultural control by the media and stressed passiveness and alienation of recipients. At the time, I noted that these fatalistic formulations were detrimental to a more dialectic view of the role played by the media, and that they led to analyses that simplified both subjective and intersubjective processes for the production and dissemination of cultural products, thus missing out on the essence of social contradictions. At that time, I analyzed the interplay between dominant interests and popular movements in order to show that dominant ideas were not randomly imposed; they 
were mutually influenced by their opposing parties. I demonstrated that actions and reactions of each social segment are continually dependent on the conditions of existence of other classes, that nothing exists in a pure state in society. My conclusion was that popular classes reacted to and resisted all types of domination, even as they did so in a shaky, ambiguous and fragmented fashion. And this took place even in a time when an authoritarian regime was in power, in a time of strong political pressure. (Motta, 1983) ${ }^{9}$.

That naïve ideas of unilateral domination enjoyed widespread acceptance in the 1970 s and early 1980 s is understandable from a historical point of view. The most serious thing is its persistence as the prevailing paradigm after so many decades of continued research, of recurring criticism, and significant changes in the correlation of forces in the country as we shall see later. During a recent review of theses and dissertations considered as the best papers written in 2004 within postgraduate programs in communication studies, a reviewer identified that the prevailing trend of master's dissertations and doctoral theses developed in the country goes on repeating the jargon that has become the paradigm of research over the past few decades: journalism manipulates the ideology behind the contents of news according to professional and market culture; it transforms everything into an spectacle, strips messages from their context and helps increase political alienation in society. There is a variation of tone, volume, topic and paths, but it continues to repeat what has become commonplace ${ }^{10}$. Therefore, there is every indication that the mediacentric paradigm remains hegemonic.

\section{THE SOCIOCENTRIC (COUNTER-HEGEMONIC) PARADIGM}

I would like now to address a totally different epistemological approach, which seems less naïve considering the contradictions inherent to Brazilian society and journalism. This current of thought is not new in the area of journalism research - it has progressively gained theoretical and methodological consistency over the past two decades, to the point where it can now be seen as a countercurrent to the hegemonic paradigm. For the purposes of this study, we have adopted the term 'sociocentric paradigm', as opposed to 'mediacentric paradigm', although I recognize that this term is not perfectly suitable. The focus moves from media to society, where the correlation of forces determines the positions, practices and contents of the media. This paradigm is not specific to journalism studies, but refers to media studies in general. However, the 
main reference is journalism as it is seen in media and political studies, for instance.

The sociocentric paradigm does not deny the importance of journalism and media in contemporary society, nor that it is of a class nature. However, it is based on more dialectic premises and fewer clichés. It focuses on civil society and social relations, trying to identify class conflicts and class segments in order to observe the advances and retreats of each social group, as well as their negotiations, alliances, and concessions. From such observations, it therefore tries to understand how each social segment strategically uses the media. The media is seen as an arena and a tool for political confrontations in the fight for visibility and the quest for power.

By presenting this innovative paradigm in journalism studies - still in its first steps - we are not merely proposing an academic exercise. Such studies introduce significant issues related to citizens' rights and democracy, the public sphere, politics as a struggle for power. A deeper analysis of such issues leads to discussions on what journalism is all about, its essence, and its role in democracy. In my opinion, this debate has already begun in Brazil, both within media companies (through readership councils, increased space dedicated to community complaints, articles written by non-journalists, debates on editorial boards, and introduction of ombudspersons, to name a few), in organized society (where we find a greater awareness of this topic, including the appearance of a large number of media criticism organizations in our country), and within civil society organizations (which have become more and more qualified to deal with the media, thanks to the more widespread concept of political and social marketing). The appearance of this new paradigm in academia is an indicator that journalism as a discipline is not ignoring the changes taking place in society.

Under this new paradigm, journalism is not seen as an all-powerful, monolithic and overwhelming "consciousness industry". Journalism becomes part of a field of competition where the interests of hegemonic groups prevail - an inevitable fact -, but also a space to be conquered through ongoing negotiation and compromising. Journalism is not seen as an activity that is closed in itself and is insensitive to social struggles - it is an arena full of contradictions whose contents tend to favor dominating interests, but which can give in to temporary or lasting pressures depending on the circumstances.

Under the sociocentric paradigm, journalism is not seen as an ideological apparatus that homogenizes culture and thought, and that 
acts necessarily at the service of a commercial rationale. It is not an autonomous depoliticizing agent, or a 'conservative dream factory' that continuously imposes a single thought. Under this paradigm, society is formed by classes, class segments, organized groups, and social movements (with different degrees of organization, confrontation and coordination); these are able to break political barriers and make their causes visible within conservative journalism. This paradigm is totally different - less naïve and more realistic - and is able to capture the nuances of political culture.

At first sight, the sociocentric paradigm described herein might be mistaken for the so-called 'Uses and Gratifications' model. In fact, that influential North American communication research model overlaps with the sociocentric attitude as both consider the audience an active actor in the communicative process. The model addresses the unbalance found in research so far, usually guided by the persuasive effects of the media. As stated by some of its authors (Katz, Blumler e Gurevitch, 1974), the 'Uses and Cratifications' model considers as a hypothesis, not a fact, the statement that mass communication is the opium of the masses - a predominating tendency at the time ${ }^{11}$.

This is where coincidences end, however. The studies known as 'Uses and Gratifications' adopt the mechanical stimulus-response model of experimental studies (independent variable-dependent variable), which has no connection with the sociocentric paradigm proposed herein. Despite the variations, the studies that follow this model are predominantly aimed at the psychological needs and gratifications of individuals that seem to have an abstract existence outside their political environment, external to social time and space, as suggested by Philip Elliott (1974, 255). Sociocentric research is based on totally different premises: social conflict, political struggle involving classes and class segments; it is not based on individuals' mental states. In my opinion, P. Elliott has produced a definitive criticism of the 'Uses and Gratifications' model by pointing out that the audiences actually seek something from the media. However, that is not the issue: what really matters is to understand the interests at stake, something that is not addressed by the North American model. Evidence from both sides of the mass communication process, says Elliott, reveals that content production and consumption processes are both conditioned by the same social structure ${ }^{12}$.

Among us, the origin of the sociocentric paradigm lies mostly in the ideas of Italian Marxist thinker Antonio Cramsci ${ }^{13}$. In a study on the development of communication research in Latin America, A. Mattelart 
(1999) described Gramsci as a passeur, someone who helps cross a border, or progress from one age to another. Gramsci's formulations were fundamental, said Mattelart, to free researchers from the passive roles of recipients, and to rediscover popular cultures and practices. In the late 1970s, Martin Barbero gave his contribution and inverted the idea of communication as a domination process, suggesting the study of domination as a communication process, therefore moving away from a manicheistic view loaded with sociological clichés ${ }^{14}$. This 'passage' did not result from journalism studies alone - it was also based on media studies in general. Nevertheless, it is valid to mention it here due to its influence on the journalism-specific studies over the past two decades. Having noticed this trend, Afonso Albuquerque (1998) coined a name for this new paradigm in journalism research: 'news production paradigm'. The new paradigm, he said, was opposed to the 'news manipulation paradigm' (mentioned above). Although his analysis does not agree with some of the points raised here, it is convergent with our views where it identifies the sociological limits of the mediacentric paradigm.

In Brazil, in parallel with gradual changes in researchers' attitudes, the country experienced a process of opening and achievement of political freedoms. The Brazilian State and the public institutions became more permeable to pressures, and therefore more representative of society as a whole. Civil society reorganized itself and began to apply a stricter control of public institutions, building new channels of expression and widening democratic debate. A large number of non-governmental organizations appeared, thus creating a very dynamic third sector. Labor organizations reclaimed the bargaining power they had lost, and new organized social movements sprouted throughout the country, with different degrees of representativeness. At the same time, Brazil also witnessed a dissemination of political parties. Although opportunism and clientelism are still the rule, it is undeniable that citizens' representation has grown at different levels in our country ${ }^{15}$.

During the same period, the media grew at a very fast pace in Brazil ${ }^{16}$. This growth followed a business rationale, but it is worth remembering that its outputs are symbolic goods that circulate publicly among a wide range of beneficiaries. The media-particularly journalism - depends on its audiences, ratings, social movements, and political culture. Its eminently public character transforms the media into a new social space. It becomes one of those places where the world is publicly constructed - an arena of confrontations, conflicts of representation and interests. Mediacentric researchers seem to ignore such movements, but the practitioners of 
the new sociocentric paradigm appear to be determined to capture this social dynamics and incorporate it into their analyses, in support of the belief that we will move from the mere repetition of essayistic clichés to a more realistic observation of the continuous game of political trade-off between journalism and society.

To a larger degree than other forms of media, journalism is gradually becoming a central arena and actor in Brazilian political culture, although certainly not a monolithic arena or actor. It has gained a relative autonomy from the State, thus becoming a place for social mediation - a space for public encounters and misencounters, alliances and confrontations. Brazilian reality today is built on a mix of life and telelife experiences, as stated by J. Almeida (2002), according to whom the media can change political power because politics has to adapt to its language. However, politics is not necessarily fully submitted to its market logic - on the contrary, the media is an environment that the other political actors contend for, and it remains an actor in itself, with its own roles and functions.

Journalistic companies, as with any other media, arrange alliances, compete for markets, attention and ratings, and need to maintain their credibility. That is why their political alliances do not always correspond to society's hegemonic political power. If there is a centrality in the media, concludes Almeida, "it is in the sense that contemporary sociability necessarily relates to the media". Whenever it is possible and necessary, the media uses less aggressive means, allows opinions opposed to its own to get through, and opens space for personalities and institutions to defend different views; all this is done in order to maintain an image of credibility and impartiality. If a particular social movement gains grounds, the media cannot ignore it; everything must naturally respect certain limits and will depend on political circumstances ${ }^{17}$.

A recent study has revealed an interesting and illustrative example of the reciprocal movement between political culture and journalism. Mauro Porto (2002) shows how a wearing-off Jornal Nacional (\# 1 national news program in Brazil) had to adapt to changes in Brazilian politics and pressures from competition, and also to face political demands and address changes in society. The risk of losing credibility among its audience due to an excessively pro-government coverage forced Rede Globo to adapt its news program to the new circumstances and introduce a more active and independent type of journalism. Porto concludes that the media need to legitimate their work before their audiences, even if that leads to a legitimacy conflict with the system. We have only 
mentioned this example to support our argument, but many others could be obtained from recent studies on Brazilian journalism.

The contradictions, possibilities and advances in the relationship between journalism and society are discussed in an article by Luiz Martins (2002), who in my opinion sets the ground for future debate. According to him, recipients have a double status vis-à-vis the press: they are consumers and/or citizens. In turn, the press would also have its double goals: higher profits and/or social responsibility. From these ambivalences, he analyses several views, from the most traditional such as the monitoring of public powers by journalism at the request of society (the concept of 4 th power), to public journalism, and other ways of engaging journalism by organized social segments. This author sets up a scale: from citizen rights granted by the press, to an inversion of this route - a civic journalism receptive to citizen rights. This scale can be refined and enlarged according to specific case studies ${ }^{18}$.

Martins also raises another issue: if citizenship as a concept is so heavily loaded with autonomy, how can such autonomy be applied through journalism? He points out that only at the beginning of this century (year 2000) did a public argumentative sphere establish itself in Brazil, with the emphasis on right, consensus and deliberation; only in these past few years have we seen enlightened and active public segments. This condition has historically caused journalism to be sensitive to social aspects only when news-values could be identified from a press point of view (newsability). However, Martins mentions some public sectors that have been relatively successful in influencing the agenda of Brazilian journalism, such as organized consumers associations, non-governmental organizations dealing with social and environmental issues, etc. He concludes that Brazilian civil society is more mature and does not waste so much energy on revolutionary shooting against the State; rather, it works continuously to put together its artillery for confrontation, and also to develop partnerships, including partnerships with the press.

In another paper, L. Martins (Martins et al, 2003) points out that social movements sometimes need to adopt a media logic, establish tactic and strategic procedures, and create factoids to break new ground in journalism. In order to understand how pluralism works in Brazilian press, R. Crispim (2003), a student supervised by Martins, studied Greenpeace's media engagement strategy; this environmental NGO uses demonstrations, dramatic actions, performances and spectacular dramatizing (newsability) to attract journalists' attention. Out of the 14 actions analyzed in 5 major Brazilian papers, aggressive engagement was 
effective in over $50 \%$ of the cases, resulting in 5 front-page headlines in the papers. It is worth pointing out that the actions reported were protests against powerful companies, such as Dow Chemicals, Red Madeiras Tropicais and Perdigão.

Nonetheless, it is not always necessary to use factoids to attract the attention of journalists. Another study (Neves Lima, 2003) revealed that the educational work developed by the Children's Rights News Agency - ANDI (Agência de Notícias dos Direitos da Infância) was able to raise awareness among journalists and modify the quantity and quality of journalistic coverage given to childhood issues in Brazil. Since 1996, ANDI has been consistently working to raise the quality of journalistic coverage on this topic in Brazil: they suggest agendas, provide information, spread news, monitor and publicize the work of the media, recognize the value of journalists by granting them the title of 'children's friends', carry out surveys, issue reports, and maintain journalists and editorial staff constantly updated on relevant issues through their wide mailing list. This intelligent strategy has broken new grounds in journalism. From 1996 to 2002, qualified coverage on this issue grew 900\%, according to Neves Lima. In addition to breaking new grounds, the quality of the coverage also improved: rather than simply dealing with minors when they were in breach of the law, articles and reports now refer to children's problems as a social issue. ANDl's example has multiplied itself, and there are now 8 similar agencies in the country; in fact, a Latin American network on children's issues is about to be created. In addition, the foundations for a Childhood \& Media Studies Chair have been set in academia, with the possibility of involving public and private universities all over Brazil.

Traquina (2002) argues that the attention given by journalism research to the issue of engagement over the past few years seems to point towards a rediscovery of the power of journalism. This author discusses the relationship between the government's, the public's and the journalists' agendas (concepts taken from Molotch \& Lester, 1993) and reveals that the role of the promoters (intentional facts promoters) has only recently become subject of research in journalism (who determines the journalistic agenda? he asks). He focuses on the influence of the journalistic agenda on the public agenda. A possible conclusion from his studies, according to Molotch \& Lester, is that "access to the journalistic field constitutes one of the sources of power relations". Those who do not have regular access to the journalistic field need to 'make news' by being in conflict with the journalistic production system, generating surprise, shock or any other form of stir. Therefore, political fight occurs on the 
central stage of a symbolic fight around building facts.

Based on innumerable studies, Traquina points out that the influence of the journalistic agenda on the public agenda is direct and immediate, whereas the influence of the public agenda on the journalistic agenda is gradual and long term - and I agree with this statement. However, Traquina warns us that the results of his research are divergent with regard to this influence. The growing complexity of the studies shows that the engagement of the public by journalism depends on the nature of the issue, the degree of sociability of individuals, the need for guidance, the geographical distance from people to the fact, as well as other factors (Traquina, 2002, 36-43). In Brazilian research, these topics have only recently been included in the academic agenda, in parallel with civil society's democratic advances. A general study on the correlation of forces between the public agenda and the journalistic agenda has not yet been done. Such study might enable us to understand the advances and retreats of the media as a social actor, and of society with regard to the media as a public space. Until then, we run the risk of continuing to repeat clichés.

\section{CONCLUSION}

It is undeniable that Brazilian journalism still works for the reduction of political debate. After all, it is part of a market-based, politically conservative, socially exclusive society, despite all its recent advances. In this context, journalism, as an activity that depends on commercial relations, could not be any different. However, such work is developed with significant and permanent contradictions, and it does not mean that our journalism is automatically allied with political power, or that it is an exclusive tool at the service of commercial interests. The survival of journalism in Brazil depends on its ability to negotiate: it cannot exist without compromise and permanent negotiation, and it is based on the advances and retreats determined by the political game. Journalism is neither monolithic nor impermeable to social pressures.

Studies cannot simply go on denouncing ideological manipulation as if it were automatic, only because the media exists according to market rules. This is an attitude that obscures contradictions. When criticizing this biased analytical view, Albino Rubim (2003) gives a warning: what should be a contemporary issue to be investigated has dangerously gained the status of unquestionable truth. He points out that politics has been undergoing important changes due to its need to adapt to the dynamics 
of media networks as a support to the contemporary political dimension. Such changes include the absorption and use of media languages and resources, but are not necessarily determined by business conditions or by the single logic of entertainment. For him, mediatized politics would only refer to the politics that exists in the contemporary public dimension of sociability, trying to adapt to this space and to its own languages.

This leads to relevant changes in political dynamics, says Rubim, but an imperative depoliticization does not follow, nor does an imposition of media logic and rationale as a superpower that rules over the social universe. Media incorporation and adaptation through journalistic newsability criteria cannot be necessarily mistaken for spectacularization, as if the media had the inherent power to automatically transform and mold everything it touches through its logic. It is true that the media determines political behaviors and potentize performances, and it is also strongly biased towards the spectacular. However, this simplistic identification between the media and public shows impoverishes the diversity of political dynamics and its actors' strategic actions (Rubim, 2003).

Similar arguments have been developed by Albuquerque (2000): attributing to the media-show the power to organize political life as a mere dramatization underestimates the relevance and subtleties of a contemporary sociability public dimension instituted by media networks. The mediatization of social life does not necessarily lead to a pernicious and overwhelming cultural imposition. The media is not the big bad wolf of politics and cultural life. For Albuquerque, a new paradigm in journalism research should: 1) stress understanding of news production processes; 2 ) try to understand the way in which extra journalistic factors condition news production processes; and 3) consider the participation of the subjects involved in this process as active actors interested in influencing news contents. The new paradigm in journalism research, says the author, should understand the political modus operandi of journalistic companies, analyze how they define their public function, understand journalists' concepts of newsability, go beyond ordinary common sense, and establish methods to identify concrete instances of manipulation.

There is, in the media, a profusion of news on social problems. The theme of human development has naturally become an everyday issue in journalism due to its natural dramaticity (poverty, indigence, starvation, endemics, unemployment, natural disasters, etc). These themes are only news, however, because they match the criteria of newsability. The rule remains the superficiality and fugacity of coverage. Still, many 
articles and reports contextualize and analyze dramatic social themes and present a plurality of viewpoints, including solutions suggested by technicians, experts and the community, in addition to info boxes containing services and guidance. There are innumerable examples of the press spontaneously embracing certain social causes, as well as several examples of press engagement strategies by organized popular segments, as we have seen above.

Negotiations, concessions and agreements between journalists and civil society are established and reviewed all the time, according to the prevailing political positions. In addition to the above mentioned topics observed in recent research, we could cite other interesting cases regarding the exercise of counter-hegemony in journalism, such as the Third Sector Information Network - RITS (Rede de Informações para o Terceiro Setor), the Ethos Institute and the IBASE. These organizations' objectives include supporting organized segments of society in their dealings with the media, a clear demonstration that the media logic has changed society and political culture. However, these organizations are also clear evidence that civil society has changed, and is now learning how to deal with the media, and to conquer media trenches. It also shows that, in spite of what the mediacentric paradigm tries to prove, there are still causes worth fighting for: reactions, resistance, tactics, conquests, occupied territories, democratic trenches. This social dynamics needs to be taken into account by a less mechanicist and fatalist type of research, which eliminates the essence of social contradictions.

How far do newspapers and networks 'embrace' the causes of organized civil society at their own will? To what extent does conservative journalism give in to pressures? To what extent does it cover social causes and treads new grounds by simply making concessions to newsability and market interests? How much can civil society's civic spirit bend journalism's professional and commercial culture and influence its agenda? How far can agreements, concessions and negotiations go? These are the questions that need to be answered by new Brazilian journalism research, not from partial or psychological studies, but from the understanding that journalism, as well as the media in general, is a social actor in the dynamic political game; an actor that gives in and denies, negotiates and retreats; a contradictory actor in its specificity; an actor that not only becomes a unique arena of contemporary sociability, but also incessantly demands its relative independence from other segments, and continuously claims its position as a legitimate public space, even though it predominantly needs to conciliate its interests to those of the hegemonic bloc. 
It is by answering these questions that Brazilian journalism studies shall gain theoretical and methodological consistency, and build a less naïve paradigm, at the same time more sociologically complex and historically specific. Research must be primarily focused on social relations, political disputes, and class and subclass confrontations; it should aim at political negotiations, strategies and alliances that are continuously established and reviewed in Brazilian society, with immediate effects on media communicative processes, and particularly on journalism. A careful look at our papers, radio and television news programs - without preconceived stances - is enough to identify the social contradictions that take place in these spheres. Our research must take into account the power of journalism as a political institution, but also needs to consider it as a social actor that is capable of giving in and compromising. Our journalism is dynamic, contradictory and unique. We need more empirical and less essayistic research; one that is more historical and less naïve; research that focuses on social aspects, and is able to capture the dynamics of the fight for consolidating democracy in our country.

* An oral presentation of this article was made at the Pre-Conference of the Association for International Media and Communication Research (AIMCR) in Porto Alegre, on July 25, 2004.

\section{NOTES}

1 It is estimated that there are approximately 500 researchers working in research groups under $\mathrm{CNPq}$ and that the number of students enrolled in postgraduate programs in communications studies comes close to three thousand. The most representative national meetings in the field are held by COMPÓS, INTERCOM, ALAIC, and SBPJor. Some of these organizations hold more than one meeting per year at national level. COMPÓS, INTERCOM and ALAIC have work groups on journalism research, and the newly created SBPJor focus exclusively on the field of journalism, which gives a sense of how abundant this field is in Brazil. On average, 45 papers are presented within COMPÓs' Journalism WG per year.

2 Considering the papers published on the press in Brazil, C. Berger identifies six trends of research: history of journalism, alternative and unionist journalism, technical books, review of the profession and of 
professionals, review of coverage, and electronic journalism. M.Pereira and J. Weinberg have established 13 categories to analyze books, articles and theses on journalism in Brazil: organizational journalism, teaching journalism, the right to communication, history of journalism, alternative journalism, journalism \& science, journalism \& economics, journalism $\&$ journalistic enterprise, international journalism, journalism \& politics, journalism language $\&$ technology, and journalism theories. Marques de Melo's review is of a historical and geographical nature.

3 The new constructivist paradigm, which is quite strong within journalism as a discipline, emphasizes that reality does not lie in the value and quality of facts per se, it is rather developed by those who watch it - where and how they watch it -, by those who select information and who leave out, by the perceptions of the ones chosen to express their opinion: "if there are rules for the selection of information and rules for its editing according to time and space available, then these selections have an intention and the pragmatic aspects and the facilitating and productive role played by journalism are clearly unveiled." (Motta, 2003a,155).

4 In a nutshell, my argument is as follows: journalistic communication is a dynamic process regarding the creation of meanings, a principle of oppositions, a game of intended effects and achieved outcomes. The level of transmission of an explicit message (objective message) refers to the act of informing (apparent contents). On the other hand, the actual level of communication is associated to an exchange of experiences where objective elements come into play, but primarily subjective and intersubjective elements (memories, emotions, feelings, passions, etc.). Journalism is continually seeking to maximize informational effectiveness by aiming at the aesthetic aspect (e.g., lead). However, many other subjective effects of meaning are conveyed that are implied during communication, which derive from both the literal meaning of words and sentences and aesthetic, ethical and moral signals in journalistic texts and discourses.

5 'Paradigm' is a tricky word, as noted earlier (Motta, 2003a). This term has been used with different meanings, where at times it signifies a philosophical or methodological model and at times it signifies a way of regarding and interpreting the world. Even Thomas Khun, the most well known author regarding the discussion on scientific paradigms, has not established a precise concept for the term. He repeatedly reformulated his concept, and his works contain 21 different definitions for paradigm. This concept will be used here to refer to a set of accomplishments acknowledged by a community as the foundations of their research approaches, thus providing conceptual and methodological principles. 
The paradigm can lie in a set of works or in a work or in a single author (Khun, 1982).

6 I will borrow this term from Venício Arthur de Lima (1996), although he used the word in English and to refer to a media-oriented society, not to refer to the paradigm.

7 At that time, little consistent research was conducted in the country; most of it was more of an essayistic nature than of a scientific nature. Importation of communications models by Brazilian research was intense. The prevailing approach was to criticize capitalism, authoritarianism and media concentration. Although some studies provide criticism, they employed American theories of communication research - hypodermic theories, theory of persuasion, theory of two-stage effects, and later the theory of gatekeepers and newsmaking, which were more sophisticated. However, critical theories - Marxism, Frankfurtian versions and French semiological Structuralism - were more in line with the activist and critical attitude towards market society. Marxism, criticism of censorship, activism, and democracy-restoring principles are mixed with communication research.

8 Marcondes Filho, Ciro (2000): Comunicação \& Jornalismo - A saga dos cães perdidos, Hacker Editores, S. Paulo.

9 At that time, I quoted the final document of a meeting of Latin American researchers that reaffirmed cultural domination, enforcement of consumerism and international interests and cultural standards to the detriment of national ones. At individual level, the document argued that communication replaces consciousness of local interests and objectives of explored groups with contents of the explorer's consciousness (João Bosco Pinto, Comunicación participatória como pedagogia de cambio, Quito, Ecuador, 1978).

10 An interview of the author with professor Mauro Porto, a reviewer of postgraduate programs in communication studies in 2003-2004 for CAPES's Commission for Higher Education Personnel Improvement.

11 The 'uses and gratifications' model was basically concerned with (1) the social and psychological origins of the (2) needs, which generate (3) certain expectations about (4) the mass media and other sources, and that lead to (5) differential patterns of media exposure (or involvement), resulting in the (6) gratification of needs and in (7) other (often unintended) consequences (Katz, Blumler e Gerevitch, 1974, 20). 
12 P. Elliott $(1974,269)$ observes that media-based and situationally-based cultures are integrally related. In a wider sense, he says, the media provides the groups it represents with an ideology - a generic map - to legitimate their activities and interests. However, "this does not mean that it consists of a monolithic system that controls society's thought and behavior". Wide internal differences can be found in the media's hegemonic ideology, as well as in its contents. More importantly, the media's ideology does not automatically determine a response from the audience. Similarly, alternative views appear here and there in society, although the ubiquity of modern media makes it more difficult for such views to integrally oppose hegemonic contents.

13 In addition to A. Gramsci, other important authors such as historians E. P. Thompson and Erick Hobsbawn, and political scientists Hannah Arendt and J. Habermas are often quoted. There is also the influence of the theoreticians of English cultural studies, such as Raymond Williams, Stuart Hall and Alan Swinglewood, other frequent references. In Latin America, an influential pioneer was Jesus Martin Barbeiro. The ideas of Brazilian educator Paulo Freire also had an indirect but gradual influence towards restoring and valuing popular culture.

14 Jesus Martin Barbero's thinking can be found in his well-known studies on mediations and popular culture in Latin America. However, regarding the arguments I am developing here, his most illustrative work is a paper presented at a meeting organized by INTERCOM in 1999, as it contains his personal views on this issue.

15 I am not arguing that Brazil is now a full democracy. The Brazilian democratic experience is barely 20 years old, and is still at a consolidating stage. Besides, the most disturbing mark of our democracy remains social exclusion. The richest ten percent respond for an income 70 times as high as that of the poorest ten percent. Seventeen million people live on less than $\$ 1$ per day. It is hard to talk about pluralism in such a concentrated society as ours. Still, Brazilian civil society goes on reorganizing itself and producing new organizations that continuously fight for their rights in disputes against the dominant sectors; they also negotiate concessions, and strategically advance and retreat according to the circumstances. A clear example of this is the growth of the so-called third sector in Brazil (also significantly known as 'solidarity sector' in sociological literature). According to some estimates, third sector organizations currently employ around two million people in Brazil, and the sector investments correspond approximately to $1.5 \%$ of national GDP (source: IBASE).

16 There are currently 4,000 radio stations (FM, SW, MW, and OT), 270 TV broadcasters and 8,000 rebroadcasters in Brazil. The total number of 
newspapers has reached 3,000, and their circulation grew $60 \%$ between 1990 and 2000 (but dropped 20\% between 2000 and 2003). It is worth pointing out that despite this recent drop in circulation, the number of publications has grown significantly. Another interesting fact is that 1,200 licenses were granted to community radio stations between 1998 and 2002 , and there are still some 8,000 applications for community radio licenses being reviewed by the Ministry of Communications. Although many of these stations have had their purposes disfigured, the majority represent local contents and programs, access and interactivity with the community, differentiated and accessible language, local campaigns, etc. We are therefore probably witnessing what can be called media of civil society, as suggested by Almeida (2002). Research in journalism, in my opinion, cannot ignore these figures (sources: ABERT, ANJ, Ministry of Communications).

$17 \mathrm{~J}$. Almeida correctly observes that media companies represent capital aimed at making profit. Therefore, it is natural that the contents of their messages should be biased towards capitalism, independently of any manipulation. That is why they need a market, and fight for consumers with other companies. They need to please their audiences and expand, but cannot do everything they wish. These companies make concessions, build political alliances and negotiate. They may side with conservative sectors (there are numerous examples in recent Brazilian politics), or grant concessions to counter-hegemonic groups (fewer examples, but generally very illustrative). J. Almeida's book correctly presents justifications for the strategic use of political marketing by popular sectors.

18 For Martins, the major turning point would consist of moving from a press that says "my social role ends with the publication of news" towards a press that said "my social role begins with understanding the genesis of the facts".

\section{BIBLIOGRAPHY}

ALBUQUERQUE, Afonso (1998). 'Manipulação editorial e produção da notícia: dois paradigmas da análise da cobertura jornalística da política', in A. A. C. Rubim e outros, Produção e recepção dos sentidos midiáticos, Petrópolis, Vozes

ALMEIDA, Jorge (2002). Marketing político- hegemonia e contra-hegemonia, S. Paulo, Fundação Perseu Abramo

BARBERO, Jesus Martin (1999). ‘Lo que la investigación latinoamericana 
de comunicación debe al Brasil: relato personal de una experiencia intercultural', in INTERCOM, Vinte anos de ciências da comunicação no Brasil, Santos

BERGER, Christa (2002). 'Jornalismo na comunicação', in M.H.Weber e outros, Tensões e objetos da pesquisa em comunicação, Porto Alegre, Sulina

BLUMLER, Jay G. e Elihu Katz (1974). The uses of mass communication, California, Sage

CRISPIM, Renata Borges (2003). Greenpeace: a guerrilha midiática como estratégia, dissertação de mestrado, Universidade de Brasília

ELLIOTT, Philip (1974). 'Uses and gratifications research: a critique and a sociological alternative', in Elihu Katz e Jay Blumler, The uses of mass communication, Califórnia, Sage

FILHO, Ciro Marcondes (2000). Comunicação e jornalismo - a saga dos cães perdidos, S. Paulo, Hacker

LIMA, Venício A. (1996). 'Cenário de representação política', XX Encontro Anual da ANPOCS

MARTINS DA SILVA, Luiz (2003). 'Jornalismo público - o social como valor notícia', in Vera França e outros, Livro da XI COMPOS

MARTINS DA SILVA, Luiz (2002). 'Imprensa e cidadania: possibilidades e contradições', in Motta, L.G. (2002), Brasília, Editora UnB

MATTELART, Armand (1999). 'Vinte anos de pesquisa ou das certezas para a ambivalência', in INTERCOM, Vinte anos de ciência da comunicação no Brasil, Santos

MEDITSCH, Eduardo (2001). O rádio na era da informação, Florianópolis, Sulina/UFSC

MELO, José Marques (1999). 'A pesquisa em jornalismo no Brasil: trajetória e perspectivas', in INTERCOM, Vinte anos de ciências da comunicação no Brasil, Santos

MOLOTCH, Harvey e Marilyn Lester (1993). Os acontecimentos midiáticos: o sentido de ocasião, in N. Traquina: Jornalimo-questões, teorias e estórias, Vega, Lisboa

MORETZSOHN, Sylvia (2002). 'Profissionalismo e objetividade: o jornalismo na contramão da política', in Motta (2002)

MOTTA, Luiz Gonzaga (2003a). 'Crise no paradigma do jornalismo. Mas, qual paradigma?', Pauta Geral, Ano 10, No. 5, Salvador, Calandra

MOTTA, Luiz Gonzaga (2003b). 'O jogo entre intencionalidades e reconhecimentos: pragmática jornalística e construção de sentidos', Comunicação \& Espaço Público, Ano VI, Nos. 1 e 2

MOTTA, Luiz Gonzaga, org. (2002). Imprensa e poder, Brasília, Ed. UnB. 
MOTTA, Gonzaga (1983). 'Cultura de resistência e comunicação alternativa popular no Brasil', Comunicação \& Política, Vol. 1, No. 1, Paz e Terra

NEVES LIMA, Inês M. S. (2003). Estudo de caso da Agência de Notícias dos Direitos da Infância, dissertação de mestrado, Universidade de Brasília

PEREIRA, Manuel Luis, e Jacques Wainberg (2000). 'A produção científica sobre o jornalismo', revista Famecos, No. 11, Porto Alegre

PORTO, Mauro (2002). 'Novos apresentadores ou novo jornalismo? O Jornal Nacional antes e depois da saída de Cid Moreira', Comunicação e Espaço Público, Ano V, Nos. 1 e 2, Universidade de Brasília

RUBIM, Antonio A. C. (2003). ‘Espetáculo, política e mídia, in V. França e outros', Livro do XI COMPOS, Porto Alegre, Sulina

SWINGEWOOD, Alan (1978). O mito da cultura de massa, Interciência, Rio de Janeiro

TRAQUINA, Nelson (2002). O estudo do jornalismo no século XX, S. Leopoldo, Unisinos

Luiz Gonzaga Motta is a journalist. He obtained his PhD in Communication Studies from the University of Wisconsin, and developed post-doctoral studies at the Universitat Autònoma de Barcelona. He is vice-president of SBPJor and editor of BJR. He is also a full Professor at the University of Brasilia (UnB). 